\title{
Metaphor and Metonymy in Food Idioms
}

\author{
Isabel Negro \\ Department of English Studies, School of Economics, Universidad Complutense de Madrid, \\ 28223 Pozuelo de Alarcón, Spain; inegro@ccee.ucm.es
}

Received: 15 May 2019; Accepted: 23 June 2019; Published: 27 June 2019

\begin{abstract}
In recent decades, the development of the Conceptual Metaphor Theory, put forward by Lakoff and other scholars. In this light, metaphor and metonymy have been found to provide a semantic motivation for a considerable number of idiomatic expressions. Within this framework, the present contribution explores the cognitive motivation of food idioms in English (e.g., 'be a cup of tea,' 'bread and butter,' 'walking on eggshells') and Spanish (e.g., darse pisto, tener mala uva, cortar el bacalao). The analysis reveals that idiomatic meaning often relies on metaphoric amalgams and metonymic chains, or on the interaction between metaphor and metonymy.
\end{abstract}

Keywords: food; idiom; metaphor; metonymy

\section{Introduction}

In recent decades, metaphor and metonymy have been investigated within the cognitive linguistics framework. Metaphor and metonymy are conceptual mechanisms that contribute to providing structure to the human conceptual system. The development of the Conceptual Metaphor Theory, put forward by Lakoff and other scholars (e.g., Lakoff and Johnson 1980; Lakoff 1987, 2006; Lakoff and Turner 1989; Kövecses 2002; cf. Ruiz de Mendoza and Pérez 2011 for assessment on the later versions) has led to research along different lines. One such line is the cognitive basis of idioms (Dobrovol'skij and Piirainen 2005; Langlotz 2006; Boers and Lindstromberg 2008). In this light, a number of studies have shown the role of metaphor and metonymy in building the meaning of numerous idiomatic expressions. Within this framework, the present article discusses the metaphorical/metonymic basis of a set of food idioms in English and Spanish.

\section{Theoretical Framework}

From a cognitive linguistics perspective, metaphor and metonymy occupy a central role in our conceptual structure.

The Conceptual Metaphor Theory is based on the following principles (Lakoff 2006):

- Metaphor is primarily a cognitive mechanism.

- Metaphor involves understanding a domain of experience (the target domain) in terms of a more concrete domain (the source domain).

- A metaphor is to be regarded as a mapping (e.g., a fixed set of conceptual correspondences) between a source domain and a target domain, where one or more features of the source are projected upon the target. As Lakoff (2006, p. 192) remarks, a metaphor is "an ontological mapping across conceptual domains," so that "the essence of meaning is understanding and experiencing one kind of thing in terms of another" (Lakoff and Johnson 1980, p. 5).

- Any linguistic metaphor, or metaphoric expression, is an instantiation of a conceptual metaphor.

While a metaphor is a mapping (i.e., a set of correspondences) between two different conceptual domains, a metonymy is a domain-internal mapping. Ruiz de Mendoza and Otal (2002, p. 58) suggest two types of metonymy based on the domain-internal nature of metonymic mappings: 
(a) Source-in-target metonymies are those in which the source domain is a subdomain of the target domain, e.g., SIGN FOR STATE ('to raise one's eyebrows'). They involve domain expansion, which consists of broadening the amount of conceptual material associated with a domain.

(b) Target-in-source metonymies are those in which the target is a subdomain of the source, for example PART-FOR-PART metonymies. They involve domain reduction and the consequent highlighting of part of a domain.

Following Ruiz de Mendoza and Galera (2014), metaphors may occur within metaphoric amalgams, and metonymies can be integrated within metonymic chains. There are two types of metaphoric amalgam: (i) A single-source metaphoric amalgam consists of integrating one of the metaphors in a complex into the conceptual configuration of the other; (ii) A double-source metaphoric amalgam results from mapping two different source domains onto the same target domain. Metonymic chains consist of combining two or more metonymies in such a way that the target domain of the first constitutes the source domain of the following one.

Metaphor and metonymy often interplay. Some authors (e.g., Radden 2000; Barcelona 2000; Ruiz de Mendoza and Díez 2002; Ruiz de Mendoza and Otal 2002) have discussed the conceptual interaction between metaphor and metonymy. In this contribution, we follow Ruiz de Mendoza and Otal (2002) that, whenever metaphor and metonymy interact, it is the latter that is subsidiary to the former. This claim results from the nature of the two mappings. While a metaphor involves two conceptual domains, a metonymy involves just one. Therefore, the two domains of metaphor cannot operate within the single domain of a metonymy. Ruiz de Mendoza and Otal (2002) propose several patterns of interaction between metaphor and metonymy:

1. Metonymic expansion of the metaphoric source or one of its correspondences, as in "to turn one's back on somebody." The action of turning one's back in the metaphoric source domain is metonymically expanded onto a situation in which a person turns his back in order to ignore somebody.

2. Metonymic reduction of the metaphoric source or one of its correspondences, as in "to have big ears." The ears metonymically stand for good hearing (ORGAN FOR SENSE).

3. This element of the source domain is then projected upon a target domain in which a person eavesdrops.

4. Metonymic expansion of a metaphoric target or one of its correspondences, as in "to clear one's throat." There is a metaphoric correspondence between clearing one's throat and coughing. The result of this metaphoric mapping is then expanded by means of a metonymy, cough being understood as a sign to attract somebody's attention.

5. Metonymic reduction of the metaphoric target or one of its correspondences, as in "to open one's eyes to something." The person who opens his eyes describes metaphorically the person who becomes aware of something important. This metaphor relies on a metonymy, inasmuch as the open eyes represent the reality seen through a person's eyes.

\section{Methodology}

We selected a sample of 50 metaphorically- or metonymically-based food idioms (25 in English and 25 in Spanish) from two dictionaries: Diccionario de dichos y frases hechas (Buitrago 2012) and Oxford Dictionary of English Idioms (Siefrig 2004).

\section{Discussion}

The source domain of food is used in both English and Spanish to represent people, as shown in the idiomatic expressions 'top banana' (most important person in a group/organization), 'bad egg' (bad/dishonest/unreliable person), 'tough cookie' (determined person), 'smart cookie' (intelligent person), 'a big cheese' (very important person), 'the cream/la flor y nata, un pedazo de pan 'a piece of bread' (very kind person), un bombón (beautiful woman), and un coco (ugly person). 
Food also provides the source for the conceptualization of money, as exemplified by the English idiom 'peanuts' (a very small amount of money).

The meaning of some idioms is based on a single-source metaphoric amalgam. It is the case of 'lemon' (silly person), 'peach' (lovely person), un mendrugo/un berzas (unintelligent person), and un bombón. The main metaphor operating in the interpretation of these expressions is PEOPLE ARE FOODS, but it needs to be conceptually enriched in order to explain why a silly person is said to be a lemon, a lovely person is said to be a peach, an attractive woman is said to be a chocolate (bombón), and an unintelligent person is said to be a crust of bread (mendrugo) or a cabbage (berza). This meaning effect is achieved through the application of a metaphor that maps a property of these food items onto a specific personality feature. Thus, sourness and little value are mapped onto lack of intelligence ('a lemon', mendrugo/berzas), and sweetness onto charm ('a peach') or attractiveness (un bombón). These metaphors combine into single-source metaphoric amalgams with the more general metaphor PEOPLE ARE FOODS. Figure 1 provides an illustration of this process.

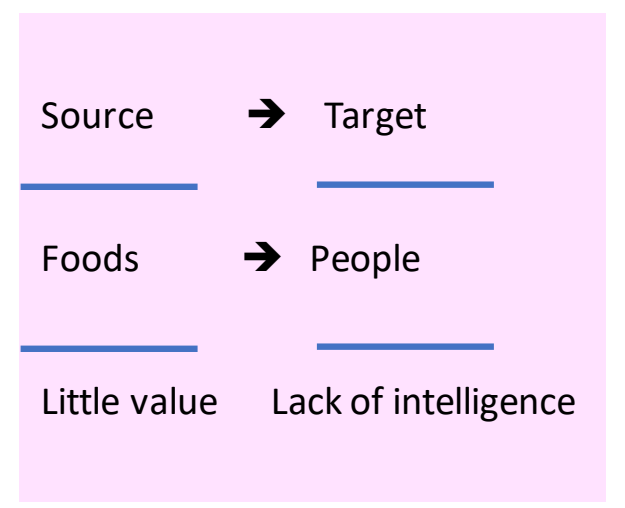

Figure 1. Metaphoric amalgam underlying the interpretation of ser un mendrugo/un berzas.

Metonymy underlies a few idioms such as 'full of beans' (full of energy') and tener mala leche 'sour milk' (to be bad-tempered). The first expression calls for an OBJECT FOR ITS PROPERTIES source-in-target metonymy, since beans make an excellent source of protein and energy. The second idiom activates a CAUSE FOR EFFECT metonymy, based on the belief that the milk supplied by the mother affected the baby's character. Other idioms are based on a metonymic complex. It is the case of 'to bring home the bacon' (earn the household income), ganarse el pan 'bread'/los garbanzos 'chickpeas'/el cocido'/las lentejas 'lentils'/las habichuelas 'beans' ('earn a living'), and 'bread and butter' (job/activity that provides you with a steady income). In the initial metonymy, the food items are made to stand for food by virtue of a GENUS FOR SPECIES target-in-source metonymy. The second metonymic process makes food stand for the money necessary to obtain it. This metonymic operation highlights the subdomain that is relevant for interpretation, in this case, MONEY. In the idiom 'bread and butter' (job/activity that provides you with a steady income), a third domain reduction process makes money stand for the activity done to earn it (PURPOSE OF THE ACTION FOR ACTION). Figure 2 schematizes this combination of metonymies.

1 Cocido is a dish made with chickpeas, meat and vegetables. 


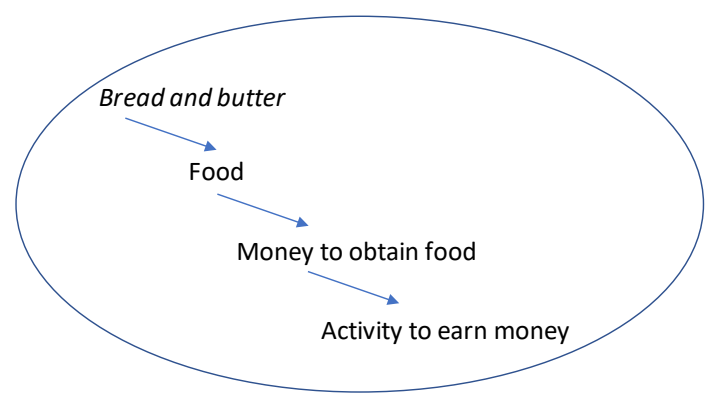

Figure 2. Metonymic complex underlying the interpretation of bread and butter.

In much the same way, a double metonymy underlies the idiom hacer buenas migas, which evokes the migrating shepherds' habit of meeting up to cook and then eat this dish ${ }^{2}$. Cooking this dish metonymically represents the good relationship between the shepherds who prepared it together. Such a good relationship then stands for good relationships between people in general.

The interpretation of a set of idioms in our sample relies on four types of interaction between metaphor and metonymy: (1) Metonymic expansion of the metaphoric source; (2) metonymic reduction of the metaphoric source; (3) metonymic reduction of the metaphoric target; and (4) metonymic expansion of the metaphoric source and metonymic reduction of the metaphoric target.

(1) Metonymic expansion of the metaphoric source

Let us consider the idiom cortar el bacalao. In the source domain, we have a fishmonger cutting cod. The action stands for the fishmonger's ability to cut cod-a fish that breaks easily into pieces-by virtue of a source-in-target metonymy. This ability is then mapped onto authority, which gives rise to the meaning 'direct, control.' The resulting pattern is one of metonymic expansion of the metaphoric source domain, as shown in Figure 3.

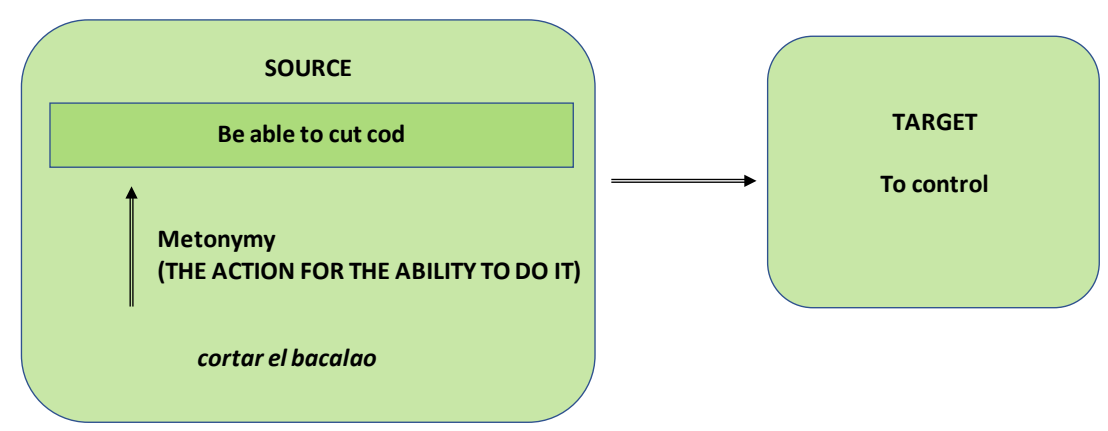

Figure 3. Metonymic expansion of the metaphoric source underlying the interpretation of cortar el bacalao.

The idiom 'spill the beans' (reveal a secret) evokes the ancient Greek method of placing black or white beans in a jar to cast votes (a white bean indicated a positive vote and a black bean was negative). If someone spilled the jar of beans, the election results would be known earlier. We highlight the result of spilling the beans by virtue of the ACTION FOR RESULt source-in-target metonymy. This metaphorical process is schematized in Figure 4.

2 The dish consists of breadcrumbs fried with garlic and paprika. 


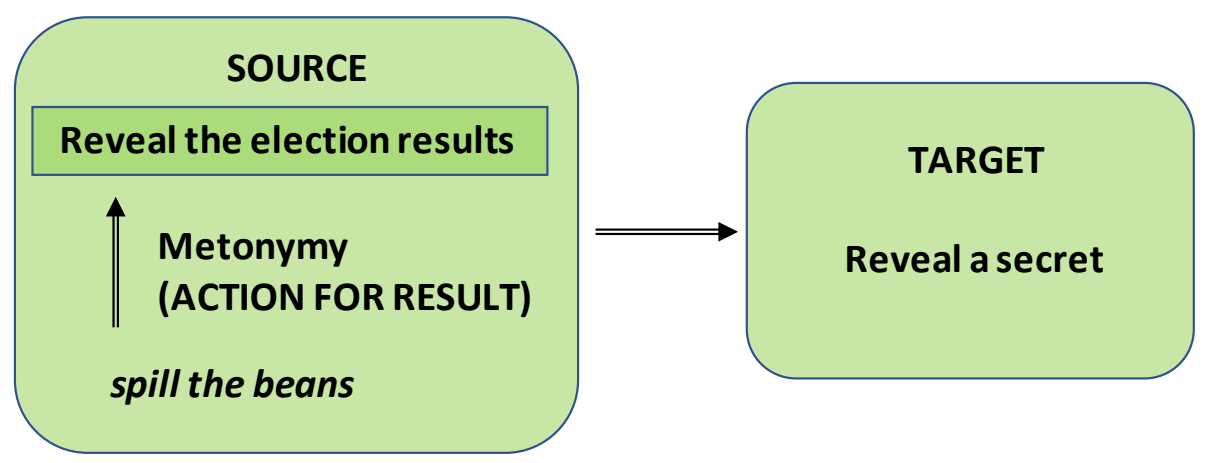

Figure 4. Metonymic expansion of the metaphoric source underlying the interpretation of 'spill the beans'.

The idiomatic expression descubrir el pastel calls for a WHOLE-FOR-PART source-in-target metonymy. Pastel refers to a meat pie eaten in the 16th and 17th centuries. Pastry cooks used to make it with more pastry than mince, so that people had to find where the meat was. The pie is made to stand for the meat inside it through an operation of metonymic expansion. Then finding the meat hidden in the pastry is mapped onto hidden information in order to yield the idiomatic meaning.

(2) Metonymic reduction of the metaphoric source

The idioms mandar a freír espárragos, 'to have your cake and eat it' and 'walking on eggshells' are all based on the SPECIFIC FOR GENERIC target-in-source metonymy. In the expression mandar a freir espárragos frying asparagus, which is a useless task, since it is easier to boil it, stands for any useless task though an operation of metonymic reduction. Making someone do something useless is then understood as keeping them away for as long as possible.

To have your cake and eat it at the same time is impossible. This situation metonymically stands for any situation in which somebody attempts to obtain two incompatible things. Trying to have two incompatible things is then understood as wanting more than one deserves or can handle.

The same SPECIFIC FOR GENERIC metonymy gives rise to the meaning of the idiom 'walking on eggshells.' The action metonymically stands for any action requiring caution. Hence the metaphorical meaning 'to act sensitively to avoid offending somebody.'

The idioms estar a la sopa boba, darse pisto and 'meat and potatoes' reflect another target-in-source metonymy, namely THE GENUS FOR THE SPECIES. In estar a la sopa boba, the word sopa evokes the broth given to the homeless outside convents in the 16th century. The soup is made to stand for food. The metonymy allows for the interpretation of being fed by someone as living at their expense. In the idiom darse pisto, pisto (fried vegetable hash) used to be a dish made up of different kinds of minced meat that well-off people ate. Again, the dish metonymically stands for food, particularly the food that only some people could afford. Eating fine foods and dishes is then metaphorically understood as showing off. In much the same way, 'meat and potatoes' stand for basic food. Basic food in the metaphorical source domain is then made to correspond with the basic needs of life, or of something in the target domain.

The expression atar los perros con longanizas is based on the metonymy THE SIGN OF WEALTH FOR WEALTH. Sausages being used as a leash indicate a person's wealth, hence the idiomatic meaning 'to live in opulence.'

A further target-in-source metonymy integrated into a metaphor is exemplified in the idiom 'to have one finger in every pie,' where the finger metonymically represents the action of eating from many pies (GESTURE FOR ACTION). The metonymy allows the action of eating to be interpreted as doing many different things.

A similar interactional pattern underlies the interpretation of the idiom tener mala uva, although the metaphorical mapping integrates a metonymic chain rather than a single metonymy. The grapes in the metaphoric source domain undergo a process of metonymic reduction that serves to highlight those 
aspects that are relevant to the metaphoric mapping. Such a process involves four consecutive domain reduction operations (see Figure 5). The first operation highlights wine by virtue of a PART-FOR-WHOLE metonymy. The second operation gives access to drinking through an OBJECT FOR ACTION metonymy. In the third operation, wine drinking is made to stand for its effects, namely aggressive behavior. Aggressiveness as a result of wine drinking is then set in metaphoric correspondence with bad temper.

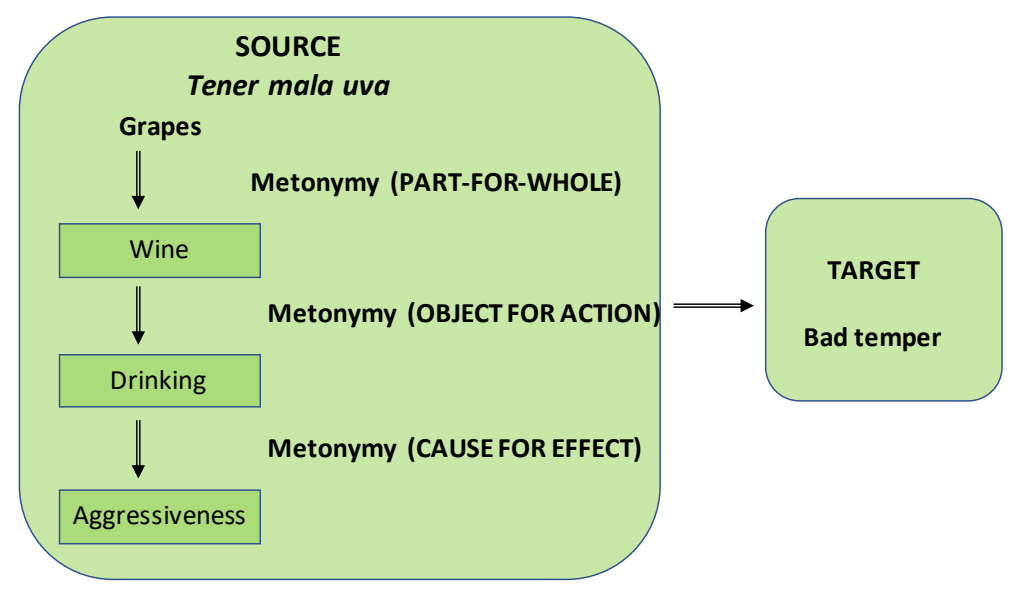

Figure 5. Metonymic chain underlying the interpretation of tener mala uva.

Another metonymic chain involving metonymic reduction underlies the expression 'it's not my cup of tea.' First, the cup of tea stands for the action of tea drinking (овJест FOR ACTION). By virtue of a further target-in-source metonymy, tea drinking is then made to stand for any pleasant activity (SPECIFIC FOR GENERIC). This metonymic process allows for the use of the idiom to refer to something that the speaker enjoys doing.

(3) Metonymic reduction of the metaphoric target

The idioms comerse el coco ('to think over and over'), tener huevos ('be courageous'), and estar hasta los huevos ('be fed up with something') profile the metaphor BODY PARTS ARE FOODS. This metaphor licenses the shift from a coconut to a person's head, and from eggs to a man's testicles. The expression comerse el coco reflects the metonymy BODY PART FOR ITS TYPICAL FUNCTIONS (Barcelona 2000, p. 265), or, as per Ruiz de Mendoza and Galera (2014, p. 113), the high-level metonymy instrument FOR FUnCTION. This target-in-source metonymy highlights the instrumental role of the head/brain in thinking. Figure 6 provides an illustration of this process.

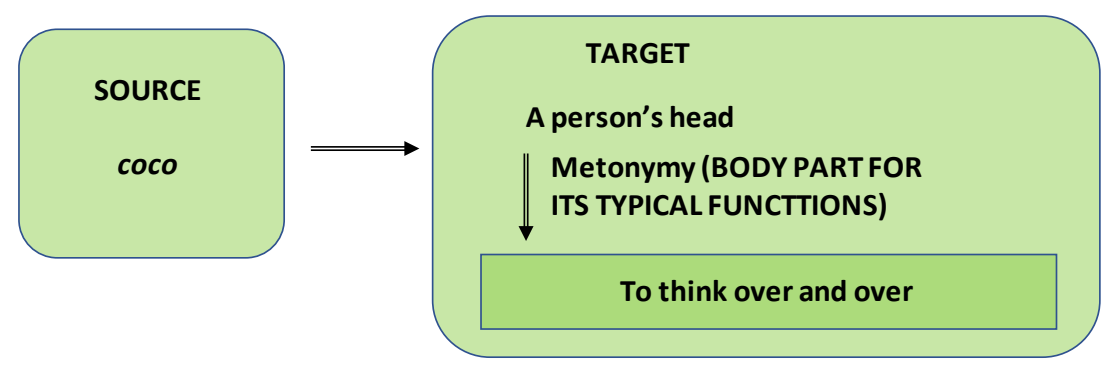

Figure 6. Metonymic reduction of the metaphoric target underlying the interpretation of comerse el coco.

In the idioms tener huevos and estar hasta los huevos, the BODY PARTS ARE FOODS metaphor subsumes the metonymy BODY PART FOR ITS TYPICAL FUNCTIONS AND FOR THE ATTRIBUTES CONNECTED WITH THEM (Barcelona 2000, p. 265), as illustrated in Figure 7. The testicles are the seat of courage (tener huevos) or anger (estar hasta los huevos). 


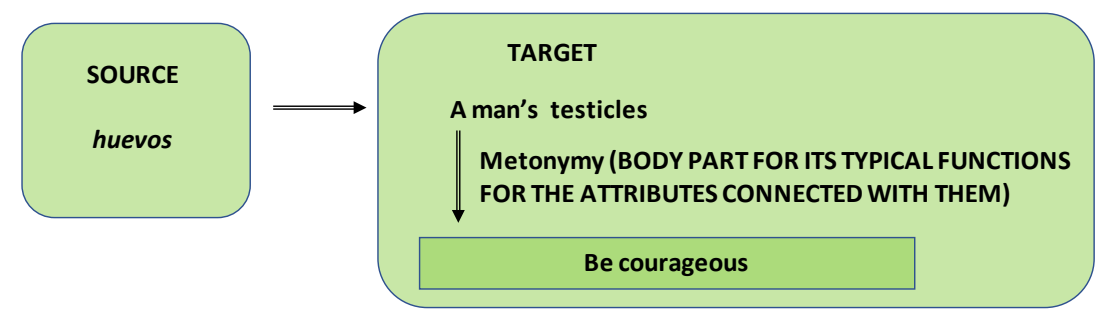

Figure 7. Metonymic reduction of the metaphoric target underlying the interpretation of tener huevos.

(4) Metonymic expansion of the metaphoric source and metonymic reduction of the metaphoric target

The meaning of the Spanish idiom poner cara de vinagre - 'to be angry/bad-tempered' - is based on a metonymic process. In the metaphoric source domain we find vinegar. The target domain depicts someone who is angry or bad-tempered. Vinegar, which is made to stand for sourness (one of its properties) through metonymic expansion, maps onto anger/bad temper in the metaphoric domain. This mapping is activated through a SIGN OF EMOTION FOR EMOTION target-in-source metonymy, whereby a person's angry expression stands for the feeling of anger. See Figure 8 for the schematization of this interactional pattern.

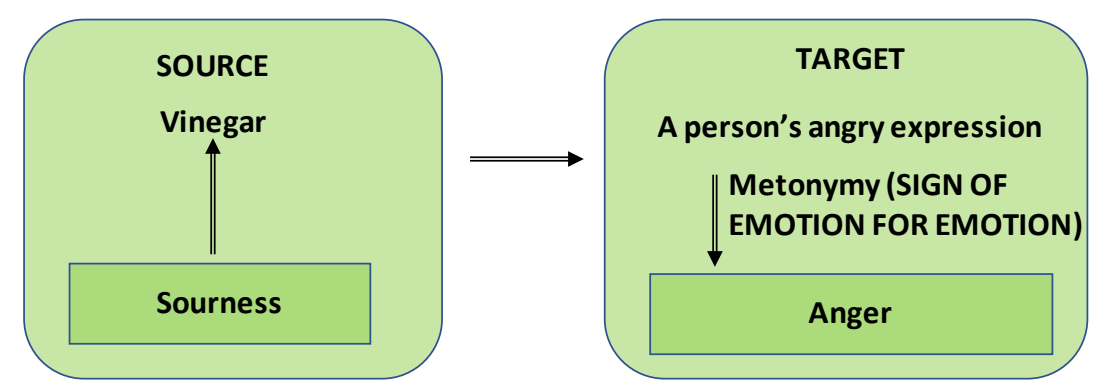

Figure 8. Metonymic reduction of the metaphoric target underlying the interpretation of estar hasta los huevos.

\section{Conclusions}

The present article has sought to give evidence of the metaphorical/metonymic basis of idioms across languages. The study of a sample of food idioms in English and Spanish has revealed (1) the role of metaphor and metonymy in construing idiomatic meaning, and (2) the interaction between metaphor and metonymy. The study has also shown that metaphor and metonymy may combine in different ways, giving rise to metaphoric amalgams and metonymic chains.

The scope of the paper being limited, further research needs to explore this topic on the basis of a large corpus.

Funding: This research received no external funding.

Conflicts of Interest: The author declares no conflict of interest.

\section{References}

Barcelona, Antonio. 2000. Metaphor and Metonymy at the Crossroads. Berlin and New York: Mouton de Gruyter.

Boers, Frank, and Seth Lindstromberg, eds. 2008. Cognitive Linguistic Approaches to Teaching Vocabulary and Phraseology. Berlin: Mouton de Gruyter.

Buitrago, Alberto. 2012. Diccionario de dichos y frases hechas. Madrid: Espasa Libros.

Dobrovol'skij, Dmitrij, and Elisabeth Piirainen. 2005. Figurative Language: Cross-Cultural and Cross-Linguistic Perspectives. Amsterdam: Elsevier.

Kövecses, Zoltan. 2002. Metaphor: A Practical Introduction. Oxford: Oxford University Press. 
Lakoff, George. 1987. Women, Fire and Dangerous Things: What Categories Reveal about the Mind. Chicago: University of Chicago Press.

Lakoff, George. 2006. The contemporary theory of metaphor. In Cognitive Linguistics: Basic Readings. Edited by Dirk Geeraerts. Berlin and New York: Mouton de Gruyter, pp. 186-238.

Lakoff, George, and Mark Johnson. 1980. Metaphors We Live By. Chicago: Chicago University Press.

Lakoff, George, and Mark Turner. 1989. More Than Cool Reason: A Field Guide to Poetic Metaphor. Chicago: University of Chicago Press.

Langlotz, Andreas. 2006. Idiomatic Creativity: A Cognitive-Linguistic Model of Idiom-Representation and Idiom-Variation in English. Amsterdam/Philadelphia: John Benjamins Publishing, vol. 17.

Radden, Günter. 2000. How metonymic are metaphors? In Metaphor and Metonymy at the Crossroads. Edited by Antonio Barcelona. Berlin and New York: Mouton de Gruyter, pp. 93-108.

Ruiz de Mendoza, Francisco José, and Olga Díez. 2002. Patterns of conceptual interaction. In Metaphor and Metonymy in Comparison and Contrast. Edited by Rene Dirven and Ralph Pörings. Berlin and New York: Mouton de Gruyter, pp. 489-532.

Ruiz de Mendoza, Francisco José, and Alicia Galera. 2014. Cognitive Modeling. A Linguistic Perspective. Amsterdam and Philadelphia: John Benjamins.

Ruiz de Mendoza, Francisco José, and José Luis Otal. 2002. Metonymy, Grammar and Communication. Granada: Comares.

Ruiz de Mendoza, Francisco José, and Lorena Pérez. 2011. The Contemporary Theory of Metaphor: Myths, Developments and Challenges. Metaphor and Symbol 26: 161-85. [CrossRef]

Siefrig, Judit. 2004. Oxford Dictionary of Idioms. Oxford: Oxford University Press.

(C) 2019 by the author. Licensee MDPI, Basel, Switzerland. This article is an open access article distributed under the terms and conditions of the Creative Commons Attribution (CC BY) license (http://creativecommons.org/licenses/by/4.0/). 